\title{
Kelayakan Buku Saku Jenis-Jenis Udang (Crustacea) Di Perairan Batam Dan Sekitarnya
}

\section{The Feasibility Pocket Book Of The Shrimp (Crustacea)At Batam Island Coastal Area}

\author{
Notowinarto $^{1 *}$ dan Sheftrie Marlita ${ }^{1}$ \\ ${ }^{1}$ Program Studi Pendidikan Biologi, FKIP, Universitas Riau Kepulauan, Batam \\ *Koresponden: notowinarto@yahoo.co.id
}

\begin{abstract}
Abstrak
Penelitian ini bertujuan mengetahui kelayakan buku saku berdasarkan hasil analisis aspek materi, grafis dan sajian buku saku jenis-jenis udang (Crustacea) di perairan Batam dan sekitarnya untuk siswa kelas X Sekolah Menengah Atas. Waktu penelitian dilaksanakan selama 2 (dua)bulan. Menggunakanmetode deskriptif dengan teknik pengumpulan data berupa angket. Teknik analisis data menggunakan uji validitas, reliabilitas, homogenitas, normalitas, dan uji Kelayakan. Hasil validitas internal dan eksternal diperoleh 20 butir pernyataan yang layak digunakan dari jumlah 25 butir pernyataan, uji reliabilitas bersifat positip atau handal, sedangkan analisis nilai data angket bersifat terdistribusi normal dan homogen. Analisis diskriptif dari 70 siswa sebagai siswa eksperimen dari 4 kelas yang diambil secara acak sederhana menunjukkan sebanyak 60 siswa $(86,70 \%)$ yang mempunyai tanggapan kelayakan terhadap buku saku dengan baik, sedangkan sisanya 10 siswa $(13,30 \%)$ yang menganggap kelayakan buku saku kurang baik serta dari jumlah yang dominan dengan skor cukup tinggi adalah 80 dengan 20 siswa memberikan tanggap baik. Dengan demikian kelayakan buku saku siswa kelas X dengan materi "Jenis-jenis Udang (Crustacea) di Perairan Batam dan Sekitarnya" masuk dalam kriteria cukup valid untuk dapat dimanfaatkan sebagai tambahan media pembelajaran
\end{abstract}

Kata Kunci: Kelayakan, Buku saku, Valid

\begin{abstract}
This study to determine the feasibility of a pocket book based on the analysis of material aspects, graphics and pocket book types of shirmp (crustacea) in the waters coastal of Batam Islands for Senior High School. The research conducted for two months. The method with data collection technique in the form of questionnaire withdata analysis techniques use validity, reliability, homogeneity, normality, and feasibility test. The result analysis: internal and external validity results obtained 20 items of statement worthy of use from the number of 25 statement items, reliability test is positive or reliable, while the analysis of questionnaire data values are normal and homogeneous distributed. Descriptive analysis of 70 students as experimental students from 4 classes taken simple randomly showed as many as 60 students (86.70\%) who had higher a feasibility response to the pocket book, while the remaining 10 students (13.30\%) who considered worthiness poor and from the dominant number with a high score is 80 with 20 students give good response. Thus the feasibility of the pocket book in the criteria is quite valid to be utilized as an additional media learning
\end{abstract}

Keywords: Feasibility,Pocket Book, Valid.

\section{PENDAHULUAN}

Bahan ajar merupakan hal yang sangat penting, karena dengan menggunakan bahan ajar akan membantu dan mempermudah guru dalam mengajar. Karena itu penulis tertarik 
untuk mengembangkan sebuah media cetak yang berupa buku saku sebagai salah satu sumber belajar. Buku saku dapat digunakan sebagai media yang menyampaikan informasi tentang materi pelajaran dan lainnya yang bersifat satu arah, sehingga bisa mengembangkan potensi siswa menjadi pelajar mandiri (Sulistyani $d k k$., 2013). Materi penelitian bersumber dari skripsi terdahulu sebagai landasan untuk bahan dasar menjadi buku saku jenis-jenis udang (Crustacea) di perairan Batam dan sekitarnya (Jumariah, $d k k$. 2015) serta buku panduan identifikasi udang dan kepiting (Lovett, 1981).

Sutikno (2013) mengartikan bahwa inti dari pembelajaran lebih menekankan pada cara-cara untuk mencapai tujuan dan berkaitan dengan bagaimana cara mengorganisasikan materi pelajaran, menyampaikan materi pelajaran dan mengelola pembelajaran atau pembelajaran adalah penyederhanaan dari kata belajar dan mengajar (BM), proses belajar mengajar (PBM) atau kegiatan belajar mengajar (KBM). Lebih lanjut dikemukan ada 3 (tiga) prinsip pembelajaran yaitu: (1)proses pembelajaran membentuk kreasi lingkungan yang dapat mengubah struktur kognitif peserta didik; (2) berhubungan dengan tipe-tipe pengetahuan yang harus dipelajari, yaitu pengetahuan fisik, sosial, dan logika; (3) dalam proses pelaksanaan pembelajaran guru harus melibatkan peran lingkungan sosial. Ciri-ciri pembelajaran meliputi memiliki tujuan, terdapat mekanisme, fokus materi jelas, adanya aktivitas siswa, tindakan guru yang cermat dan cepat, terdapat pola aturan yang ditaati guru dan siswa dalam proporsi masing-masing, limit waktu untuk mencapai tujuan pembelajaran dan adanya evaluasi. Sedangkan pandangan Hamalik (2003) dalam Rusman (2012) mengatakan bahwa pembelajaran sebagai suatu kombinasi yang tersusun meliputi unsur manusia, material, fasilitas, perlengkapan dan prosedur yang saling mempengaruhi untuk mencapai tujuan pembelajaran

Pemilihan materi jenis-jenis udang (Crustacea) dikarenakan wilayah Kota Batam sebagai daerah kepulauan dengan karakteristik perairan yang memiliki jenis-jenis udang cukup beragam. Spesifikasi produk diharapkan dalam penelitian pengembangan adalah sebagai berikut; Buku saku berupa media cetak dengan materi yang berupa teks dan gambar yang dicetak berwarna (full colour), terdiri dari materi umum tentang klasifikasi dan kunci determinasi jenis-jenis udang (Crustaceae), menggunakan bahasa Indonesia dan bahasa Inggris. 


\section{METODE PENELITIAN}

Penelitian inidilakukan di SMAN 5 Batamdengan subjek sampel adalah siswa kelas X, dimulai pada selama 2 (dua) bulan.Berdasarkan permasalahan penelitian bersifat deskriptif yakni untuk mengetahui kelayakan dari buku saku Jenis-jenis Udang Crustacea di Perairan Batam dan Sekitar yang bersumber dari pengembangan materi kompetensi dasar Animalia (Dunia Hewan) - Filum Arthropoda (Hewan Berbuku-buku), subfilum Crustacea (Udangudangan) buku Biologi untuk SMA/MA kelas X - Kurikulum 2013 (Irnaningtyas, 2013) dan hasil penelitian Jumariah, $d k k$ (2016) Struktur Komunitas Udang (Crustacea) di Perairan Kecamatan Bulang Kota Batam.

Tahapan model pengembangan merujuk pada langkah sebagai berikut: (1) Membuat desain produk berupa buku saku sesuai standar fisik, format, bobot materi dan kebahasaan; (2) Validasi dan revisi desain oleh Dosen ahli media dan ahli materi; kemudian (3) Melakukan uji coba pendahuluan terhadap angket dengan jumlah responden sebanyak 35 siswa (1 kelas) dan ujicoba lanjut setelah di validasi dan direliabilitaskan instrumen angket serta revisi produk sebagai tahapan terakhir.

Ujicoba lanjut untuk mendapatkan informasi kelayakan buku akan dijadikan produkdengan mengambil sebanyak 70 siswa dari populasi terjangkau yakni dari 4 kelas yang tersisa, yaitu data yang diperoleh dari pengisian skor pada instrumen angket pilihan dikotomi dengan jumlah butir-butir pertanyaan dengan jawaban "Ya atau Tidak" sebanyak 25 butir pertanyaan.

Uji coba instrumen pendahuluan, dimaksudkan untuk mengetahui apakah instrumen yang disusun benar-benar instrumen yang baik, ditunjukan oleh tingkat kesahihan (validitas) menggunakan analisis Point Biserial Correlation ( $\mathrm{r}_{\mathrm{pbis}}$ ), dan tingkat keandalan (reliabilitas) menggunakan analisis Formula Kuder Richardson (KR-20).

Teknik analisis data lanjutan dalam penelitian ini menggunakan statistik deskriptif dan statistik inferensial. Kemudian data yang sudah diperoleh tersebut dianalisis sebagai uji prasyarat datayang meliputi: a) Pengujian Normalitas data; b) Pengujian Homogenitas data; dan c) Pengujian Kelayakan Buku Saku berdasarkan nilai range kriteria kelayakan buku saku (Sudjana, 1990 dalam Rachmawaty dan Reza. 2013). 


\section{HASIL DAN PEMBAHASAN}

Dari hasil uji pendahuluan terhadap angket instrumen dan buku sakuyang dihitung melalui pendekatan validitas internal, validitas eksternal dan uji reliabilitas untuk mengetahui soal yang digunakan termasuk kedalam soal yang memenuhi kriteria valid dan handal dengan hasil sebagai berikut; a) Analisis diskriptif 2 orang validator dengan keahlian media dan keahlian materi menunjukkan bahwa ahli media memberikan bobot 70 poin dengan aspek (bahasa, materi, penyajian, grafis dan aspek ketertarikan peserta didik) dari buku saku umumnya baik; b) sedangkan ahli materi memberikan nilai 82 poin karena bobot materi sudah sesuai dengan kompetensi materi yang tercangkup dalam buku pelajaran.

Pada uji ketahapan berikutnya yakni uji validitas eksternal/empiristerhadap instrumen diperoleh nilai $\mathrm{r}$ kritis dari daftar tabel nilai $\mathrm{r}$ product moment Pearson tabel $\left(\mathrm{r}_{\text {tabel }}\right.$, maka diperoleh hasil $\mathrm{r}_{\text {hit }}>\mathrm{r}_{\text {tab }}$ sebanyak 20 butir pernyataan dinyatakan valid serta 5 butir

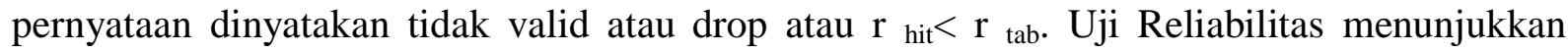
bahwasebanyak 20 butir yang tervalidasi dalam instrumen angket tersebut dinyatakan reliable (handal). Hasiluji data diskriptif instrumenyang diambil secara sampel acak sederhana pada kelas 4 kelas sebanyak 70 siswa atau sebesar 37\% dari total 190 siswa. Berdasarkan check list dari angket yaitu tanggapan: Ya (nilai $=1 /$ satu) dan Tidak (nilai $=0 /$ nol) dan semua jawab yang benar dikonversikan dengan nilai 4 (empat).

Tabel 1. Rekapitulasi hasil perhitungan statistik deskriptif nilai kelayakanbuku saku pada Kelas MIPAdi SMAN 5 Batam.

\begin{tabular}{clc}
\hline No & \multicolumn{1}{c}{ Statistik Deskriptif } & Nilai Kelayakan Buku Saku \\
\hline 1 & Jumlah Sampel (n) & 70 \\
2 & Jumlah Total Data $\left(\sum\right)$ & 5315 \\
3 & Data Maksimum (Max) & 100 \\
4 & Data Minimum (Min) & 50 \\
5 & Rentang (r) & 50 \\
6 & Rerata (Mean) & 75,93 \\
7 & Modus (Mo) & 80 \\
8 & Median (Me) & 75 \\
9 & Simpangan Baku $(S)$ & 11,89 \\
10 & Varian $\left(S^{2}\right)$ & 141,52 \\
\hline
\end{tabular}




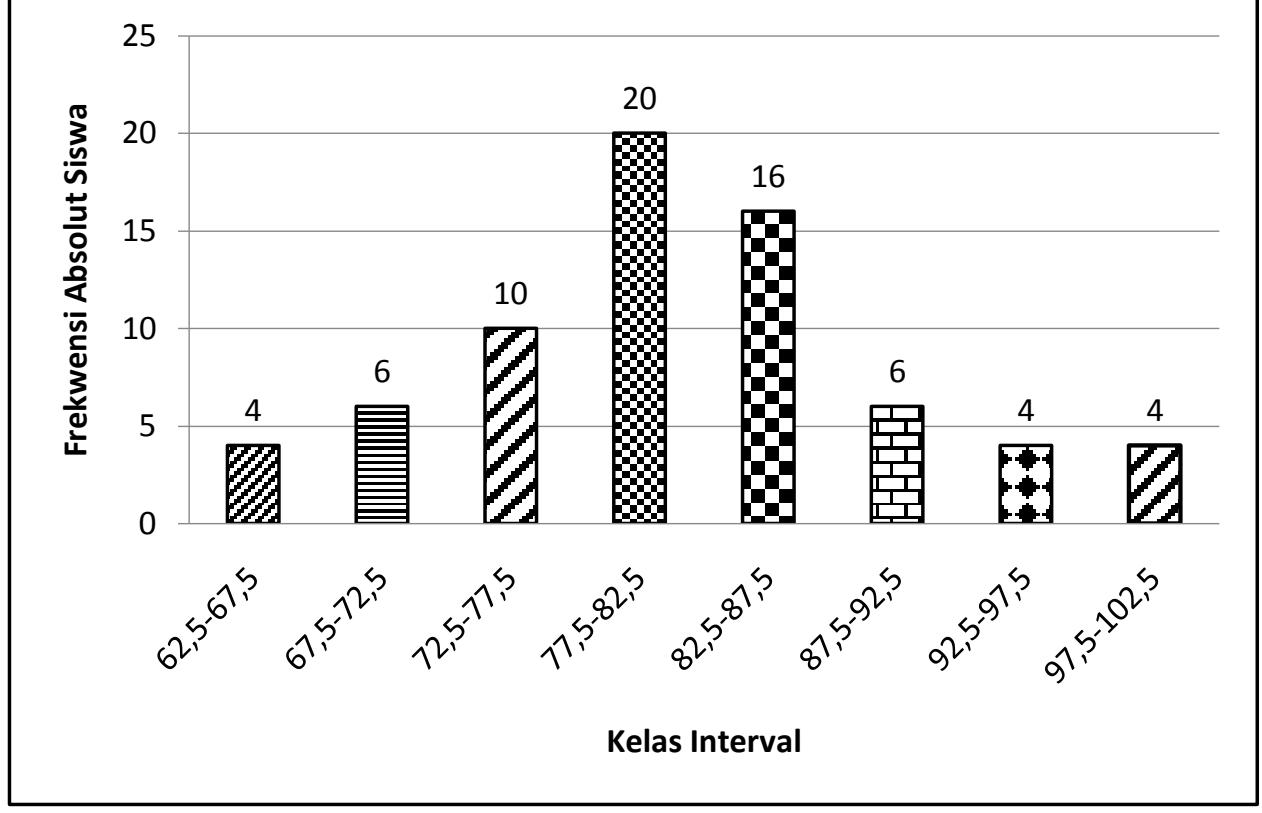

Gambar 1. Nilai Kelayakan Terhadap Buku Saku

Hasil identifikasi kategori penilaian kecenderungan atau baik tidaknya kelayakan buku di sekolah pada 4 (empat) kategori yaitu baik, cukup baik, kurang baik dan sangat kurang baik. Rekapitulasi hasil klasifikasi dibuat kategori kecenderungan berdasarkan basis nilai frekwensi absolut yang diperoleh pada tabel distribusi frekwensi disajikan dalam Tabel 2.

Berdasarkan Tabel 2. secara umum klasifikasi persepsi siswa kelas X terhadap kelayakan buku saku adalah baik. Hal tersebut disimpulkan bahwa dari 70 siswa, sebanyak 50 siswa atau sebesar 71,43\% yang memiliki pendapat baik sedangkan 16 siswa atau 22,86\% mungkin buku saku dianggap belum baik dan perlu perbaikan. Nampaknya hasil diatas sangat didominasi oleh siswa yang cukup mengerti akan keanekaragaman hewan air khususnya udang-udangan serta lingkungan kehidupan mangrove atau bakau di area pesisir.

Tabel2.Klasifikasi Kelayakan Siswa kelas X Terhadap Buku Saku

\begin{tabular}{|c|c|c|c|c|}
\hline \multirow[b]{2}{*}{ No } & \multirow[b]{2}{*}{ Skor } & \multicolumn{2}{|c|}{ Frekuensi } & \multirow{2}{*}{ Keterangan } \\
\hline & & Absolut & Relatif (\%) & \\
\hline 1 & $>80$ & 50 & 71,43 & Baik \\
\hline 2 & $70<X \leq 80$ & 16 & 22,86 & Cukup Baik \\
\hline 3 & $55<X \leq 71$ & 4 & 5,71 & Kurang Baik \\
\hline 4 & $X \leq 55$ & 0 & 0 & Sangat Tidak Baik \\
\hline & TOTAL & 70 & 100.00 & \\
\hline
\end{tabular}


Hasil pengujian prasyarat data ini meliputi: a) Pengujian normalitas data; b) Pengujian homogenitas data; dan c) Pengujian kelayakan buku saku. Hasil olah data sebagai berikut; hasil angket terdistribusi normal dengan interpretasi bahwa sebaran data yang diperoleh berasal dari populasi yang sama yakni kelas X dengan kemungkinan ada keseragaman pengetahuan terhadap keanekaragaman jenis udang; Uji homogenitas populasi dilakukan dengan menggunakan uji barlett pada taraf signtifikansi $\alpha=0,05$. Disimpulkan bahwa data tersebut bersifat homogen atau berasal dari variansi populasi yang sama.Dengan telah terujinya normalitas data dan homogenitas variansi populasi kelompok data maka telah memenuhi persyaratan analisis untuk menguji lebih lanjut yaitu uji kelayakan diskriptif buku saku.

Tabel 3. Rekapitulasi Hasil Perhitungan Uji Normalitas

\begin{tabular}{ccccc}
\hline Nilai Kelayakan & Jumlah Siswa & $\mathbf{L}_{\mathbf{0}}$ & $\mathbf{L}_{\mathbf{t}}$ & Kesimpulan \\
\hline Buku Saku & 70 & 0,1035 & 0.1498 & Berdistribusi Normal \\
\hline
\end{tabular}

Tabel 4. Rekapitulasi Hasil Perhitungan Uji Homogenitas

\begin{tabular}{cccccccc}
\hline $\begin{array}{c}\text { Nilai } \\
\text { Kelayakan }\end{array}$ & $\mathbf{n}$ & $\mathbf{d b}=(\mathbf{n}-\mathbf{1})$ & $\mathbf{1} / \mathbf{d b}$ & $\mathbf{S}^{\mathbf{2}}$ & $\mathbf{L o g} \mathbf{S}^{\mathbf{2}}$ & $\mathbf{d b} \mathbf{S}^{\mathbf{2}}$ & $\mathbf{d b} \mathbf{L o g} \mathbf{S}^{\mathbf{2}}$ \\
\hline Buku Saku & 70 & 69 & 0,01 & 141,52 & 2,151 & 9764,88 & 148,42 \\
\hline
\end{tabular}

Analisis hasil data untuk kelayakan buku saku bersifat semi inferensial dilakukan dengan mencari nilai $F_{\text {kelayakan }}$ Buku Saku berdasarkan data yang diperoleh setelah data dianggap sudah normal dan homogen. Pendekatan perhitungan menggunakan dengan mencari nilai rata-rata kemudian dibandingkan dengan nilai pada Sudjana, (1990)dalam Rachmawaty dan Reza (2013). Hasil olah data menunjukkan bahwa nilai $K=75,92$ masuk dalam katagori cukup valid produk buku saku untuk dapat dilanjutkan pemanfaatannya juga dapat dinyatakan format dan konten materi buku sakuternyata sudah dapat diterima sebagai tambahan informasi yang cukup baik dalam materi pembelajaran kompetensi dasar dari keanekaragaman jenis udang yang ada di sekitar perairan Kota Batam.

Berdasarkan klasifikasi nilai termasuk katagori baikcukup baik, nilainya mencapai angka sebesar $86,70 \%$ sisanya sebesar $13,30 \%$ menganggap buku saku tidak baik atau tidak representatif. Tanggapan tersebut sangat mungkin terjadi karena performance buku saku itu unik dan mempunyai daya tarik tertentu atas tambahan pengetahuan akan hewan air yang 
merupakan salah satu jenis makanan laut yang paling disukai. Menurut Notowinarto dan Sudirman (2015) pada hasil analisis eksperimen pra-modul materi keanekaragaman ekinodermata dan ikan, menunjukkan bahwa adanya makna penting dalam pencapaian pengembangan pra-modul yang cukup efektif.

Dinyatakan oleh Arsyad (2015) bahwa pada prinsipnya media yang kreatif dalam proses pembelajaran akan mendatangkan solusi cerdas. Sangat diperlukan suatu strategi khusus untuk dapat meningkatkan nilai kesadaran dan partisipasi siswa terhadap kondisi lingkungan melalui mediasi salah satunya adalah buku saku. Karena itu langkah yang diperlukan untuk peningkatan daya tanggap siswa adalah menstimulir kegiatan dalam proses belajar mengajar secara kreatif dan terpadu, yakni mencakup perencanaan, pelaksana dan evaluasi. Sedangkan Rukmana, $d k k$.(2016) menyatakan bahwa ada hubungan antara motivasi belajar siswa terhadap hasil belajar siswa yang signifikan apabila seorang guru wajib berusaha untuk selalu kreatif menciptakan media pembelajaran atau alat peraga yang sesuai dan menarik minat siswa. Disamping itu buku saku digunakan sebagai alat bantu yang menyampaikan informasi tentang materi pelajaran dan lainnya yang bersifat satu arah, sehingga bisa mengembangkan potensi peserta didik menjadi pelajar mandiri.

\section{KESIMPULAN}

Dapat disimpulkan bahwa buku saku tentang "Jenis-jenis Udang (Crustacea) di Perairan Batam dan Sekitarnya" yang diperuntukan siswa kelas X SMAN 5 Batam dapat diterima dan layak sebagai buku saku yang baik. Bahwa produk buku saku tersebut masih memerlukan revisi atas fisik maupun media pada tataran dasar yakni bila ditinjau dari aspek materi, konstruk, dan bahasa serta minat baca siswa atas pengetahuan kompetensi yang dibahas atau dijadikan objek materi pembelajaran dalam buku saku sehingga dapat dipercaya dan layak dipakai dalam proses pembelajaran.

\section{REFERENSI}

Arsyad, A. 2015. Media Pembelajaran. Grafindo Persada. Jakarta.

Irnaningtyas. 2013. Biologi Untuk SMA/MA Kelas X. Erlangga. Jakarta 
Jumariah, Agustina, F., dan Notowinarto. 2015. Struktur Komunitas Udang (Crustacea) di Sungai Teluk Sepaku, Kelurahan Pulau Buluh Kecamatan Bulang Kota Batam. Simbiosa. Vol 4(1): 118-131.

Lovett, D.L. 1981. A Guide The Shrimp, Prawns, Lobsters, And Crabs Of Malaysia And Singapore. Universiti Pertanian Malaysia, Malaysia.

Notowinarto dan Sudirman, D. 2015. Analisis Pra-modul Materi Keanekaragaman Ekinodermata dan Ikan Berbasis Kepulauan.Jurnal Pendidikan Lentera (JPL) No.2 Vol.2 Juni September 2015. Dinas Pendidikan Kabupaten Bondowoso, Jawa Timur. ISBN: 2355-16666

Rachmawaty dan Ristanti, R.P., 2013. Kaidah Penulisan, Pengembangan dan Penilaian Buku Saku. Makalah Tugas program Studi: Pendidikan Bahasa dan Sastra Indonesia. Fakultas Keguruan dan Ilmu Pendidikan Universitas Lampung. Lampung.

Rukmana, P.A.,Sudirman, D.,dan Notowinarto. 2016.Hubungan Kreativitas Guru Dalam Mengajar Biologi Terhadap Motivasi dan Hasil Belajar Siswa di SMA Negeri 8 Batam. Skripsi. Pendidikan Biologi,FKIP Universitas Riau Kepulauan. Batam

Rusman. 2012. Model-model Pembelajaran. PT Rajagrafindo Persada, Jakarta.

Sulistyani, N.H.D., Jamzuri, dan D.T. Raharjo. 2013. Perbedaan Hasil Belajar Siswa Antara Menggunakan Media Pocket Book dan Tanpa Pocket Book Pada Materi Kinematika Gerak Melingkar Kelas X. Jurnal Materi dan Pembelajaran Fisika. Vol. 1(1): 164.

Sutikno, S. (2013). Belajar dan pembelajaran. Holistica, Lombok. 